Огляди літератури, оригінальні дослідження, погляд на проблему, ювілеї

УДК 613.6.015+616.89: 616.891: 616.8-008.64: 613.6.06

DOI 10.11603/1811-2471.2018.v0.i3.9148

\title{
ОСОБЛИВОСТІ СУЇЦИДАЛЬНОЇ ПОВЕДІНКИ ХВОРИХ НА ПАРАНОЇДНУ ШИЗОФРЕНІЮ З РІЗНИМИ КЛІНІКО-ПСИХОПАТОЛОГІЧНИМИ ТА СОЦІАЛЬНО-ПСИХОЛОГІЧНИМИ ХАРАКТЕРИСТИКАМИ
}

\author{
Вінницький національний медичний університет імені М. І. Пирогова
}

РЕЗЮмЕ.Шизофренія-це тяжке психічне захворювання, що супроводжується високим ризиком суїцидальної поведінки.

Мета дослідження - вивчити особливості суїцидальної поведінки хворих на параноїдну шизофренію в контексті виразності позитивної, негативної та загальної симптоматики шизофренії, а також соціальної підтримки хворих.

Матеріал і методи. За дотримання принципів біомедичної етики було клінічно обстежено 53 чоловіки та 49 жінок, хворих на параноїдну шизофренію, з оцінкою вираженості симптоматики шизофренії за допомогою шкали PANSS та обстеження з використанням шкали MSPSS.

Результати. У хворих з суїцидальними думками та суїцидальними діями виявлено достовірно вищі показники маячення, галюцинацій, збудження, розладів мислення, усіх складових негативної симптоматики, тривоги, депресії, малоконтактності, зниження критичності до свого стану, а також інтегральних показників виразності психотичної симптоматики, позитивної та негативної симптоматики, депресії, анергії і порушень мислення. У хворих з суїцидальними діями показники вираженості психопатологічної симптоматики та відмінності, порівняно із хворими з відсутністю суїцидальних тенденцій, більші, ніж у хворих з суїцидальними думками. У хворих 3 суїцидальними тенденціями $€$ достовірно нижчими показники соціальної підтримки сім'ї, друзів та значущих інших; ці тенденції виявлено у чоловіків, у жінок та у всіх хворих в цілому, при цьому у хворих з суїцидальними діями ці показники є надзвичайно низькими, особливо у чоловіків.

Висновки. Виявлені закономірності свідчать, що хворим на параноїдну шизофренію з суїцидальною активністю притаманна загалом більша виразність психопатологічної симптоматики, ніж хворим без суїцидальних тенденцій; як основні предиктори суїцидальної поведінки у хворих на параноїдну шизофренію можуть розглядатися висока вираженість негативної симптоматики, маячення, галюцинацій, а також тривоги і депресії, а також те, що хворим на параноїдну шизофренію з суїцидальними тенденціями притаманний низький рівень соціальної підтримки сім'ї, друзів та значущих інших; більшою мірою ця тенденція виражена у чоловіків.

ключовІ СлОВА: параноїдна шизофренія; суїцидальна поведінка.

Вступ. Шизофренія $€$ однією з основних про6лем сучасної психіатрії [1-6]. Це тяжке психічне захворювання, що супроводжується високим ризиком суїцидальної поведінки [7-9]. Серед основних причин підвищеного суїцидального ризику при шизофренії - вплив психопатологічної шизофренічної симптоматики, а також порушення соціального функціонування та соціальної адаптації хворих [10-13]. Дотепер ряд важливих питань, пов'язаних із суїцидальною активністю хворих на шизофренію, зокрема, щодо особливостей зв'язку її з симптоматикою шизофренії та соціальною підтримкою хворих, залишаються недостатньо вивченими.

Мета - дослідити особливості суїцидальної поведінки хворих на параноїдну шизофренію в контексті виразності позитивної, негативної та загальної симптоматики шизофренії, а також соціальної підтримки хворих.

Матеріал і методи дослідження. 3 дотриманням принципів біомедичної етики нами було клінічно обстежено 102 хворих (53 чоловіки та 49 жінок) на параноїдну шизофренію (код за MKX-10 F20.00), які перебували на стаціонарному ліку- ванні у Вінницькій обласній психоневрологічній лікарні імені О. І. Ющенка за період 2015-2018 роки, і надали усвідомлену згоду на участь у дослідженні. Середній вік обстежених хворих чоловіків склав $(33,6 \pm 5,0)$ років, жінок - $(36,0 \pm 5,9)$ років. Обстеження у вигляді напівструктурованого клінічного інтерв'ю включало стандартне клінікопсихопатологічне дослідження з оцінкою вираженості позитивної, негативної та загальної симптоматики шизофренії з використанням шкали оцінки позитивних і негативних синдромів Positive and Negative Syndrome Scale - PANSS (S. Kay, L. Opler, A. Fiszbein, 1987), а також багатовимірної шкали сприйняття соціальної підтримки - MSPSS Д. Зімет в адаптації В. М. Ялтонського та Н. А. Сироти (1991). Статистичний аналіз даних включав описову статистику та міжгруповий аналіз розбіжностей за допомогою непараметричного тесту Манна-Уїтні. Прийнятним вважали $95 \%$ рівень статистичної достовірності розбіжностей $(p<0,05)$.

Результати й обговорення. Вивчення особливостей клінічної симптоматики шизофренії у хворих з різними формами суїцидальної поведін- 
Огляди літератури, оригінальні дослідження, погляд на проблему, ювілеї ки дозволило встановити ряд цікавих закономір-

симптоматики шизофренії в контексті наявності ностей. Результати аналізу психопатологічної

суїцидальних думок наведено в таблиці 1.

Таблиця 1. Показники позитивної, негативної та загальної симптоматики за даними шкали PANSS у хворих на параноїдну шизофренію з наявністю та відсутністю суїцидальних думок

\begin{tabular}{|c|c|c|c|c|c|c|c|c|c|}
\hline \multirow[b]{2}{*}{ Симптом } & \multicolumn{3}{|c|}{ Усі хворі } & \multicolumn{3}{|c|}{ Чоловіки } & \multicolumn{3}{|c|}{ Жінки } \\
\hline & $\begin{array}{c}\text { без суїци- } \\
\text { дальних } \\
\text { думок }\end{array}$ & $\begin{array}{c}\text { наявністю } \\
\text { суїцидаль- } \\
\text { них думок }\end{array}$ & $\mathrm{p}$ & $\begin{array}{l}\text { без суїци- } \\
\text { дальних } \\
\text { думок }\end{array}$ & $\begin{array}{l}\text { 3 наявністю } \\
\text { суїцидаль- } \\
\text { них думок }\end{array}$ & $p$ & $\begin{array}{c}\text { без суїци- } \\
\text { дальних } \\
\text { думок }\end{array}$ & $\begin{array}{l}\text { з наявністю } \\
\text { суїцидаль- } \\
\text { них думок }\end{array}$ & $\mathrm{p}$ \\
\hline 1 & 2 & 3 & 4 & 5 & 6 & 7 & 8 & 9 & 10 \\
\hline \multicolumn{10}{|c|}{ Позитивна симптоматика } \\
\hline Маячення & $4,90 \pm 1,06$ & $5,83 \pm 0,66$ & $<0,01$ & $5,26 \pm 0,86$ & $5,73 \pm 0,70$ & $<0,05$ & $4,58 \pm 1,13$ & $6,00 \pm 0,58$ & $<0,01$ \\
\hline $\begin{array}{l}\text { Розлади } \\
\text { мислення }\end{array}$ & $3,93 \pm 0,93$ & $4,37 \pm 0,94$ & $<0,05$ & $4,26 \pm 1,00$ & $4,64 \pm 1,00$ & $>0,05$ & $3,64 \pm 0,76$ & $3,92 \pm 0,64$ & $>0,05$ \\
\hline Галюцинації & $3,10 \pm 1,54$ & $4,46 \pm 1,17$ & $<0,01$ & $3,13 \pm 1,38$ & $4,36 \pm 1,29$ & $<0,01$ & $3,08 \pm 1,68$ & $4,62 \pm 0,96$ & $<0,01$ \\
\hline Збудження & $3,61 \pm 1,01$ & $3,80 \pm 1,02$ & $>0,05$ & $3,42 \pm 0,96$ & $3,86 \pm 1,08$ & $<0,05$ & $3,78 \pm 1,05$ & $3,69 \pm 0,95$ & $>0,05$ \\
\hline Ідеї величі & $1,36 \pm 1,01$ & $1,34 \pm 1,08$ & $>0,05$ & $1,52 \pm 1,39$ & $1,23 \pm 0,87$ & $>0,05$ & $1,22 \pm 0,48$ & $1,54 \pm 1,39$ & $>0,05$ \\
\hline $\begin{array}{l}\text { Підозріливість, } \\
\text { ідеї переслі- } \\
\text { дування }\end{array}$ & $3,85 \pm 1,37$ & $3,94 \pm 1,19$ & $>0,05$ & $3,87 \pm 1,41$ & $4,00 \pm 1,11$ & $>0,05$ & $3,83 \pm 1,36$ & $3,85 \pm 1,34$ & $>0,05$ \\
\hline Ворожість & $3,45 \pm 1,21$ & $3,60 \pm 1,12$ & $>0,05$ & $3,45 \pm 1,15$ & $3,59 \pm 1,01$ & $>0,05$ & $3,44 \pm 1,27$ & $3,62 \pm 1,33$ & $>0,05$ \\
\hline \multicolumn{10}{|c|}{ Негативна симптоматика } \\
\hline $\begin{array}{l}\text { Притуплений } \\
\text { афект }\end{array}$ & $3,91 \pm 1,11$ & $5,00 \pm 0,97$ & $<0,01$ & $4,23 \pm 1,02$ & $4,77 \pm 0,92$ & $>0,05$ & $3,64 \pm 1,13$ & $5,38 \pm 0,96$ & $<0,01$ \\
\hline $\begin{array}{l}\text { Емоційна } \\
\text { відгородженість }\end{array}$ & $3,82 \pm 1,10$ & $4,91 \pm 0,89$ & $<0,01$ & $4,10 \pm 0,98$ & $4,82 \pm 0,91$ & $<0,05$ & $3,58 \pm 1,16$ & $5,08 \pm 0,86$ & $<0,01$ \\
\hline $\begin{array}{l}\text { Труднощі у } \\
\text { спілкуванні }\end{array}$ & $3,73 \pm 0,95$ & $4,97 \pm 0,98$ & $<0,01$ & $4,03 \pm 0,91$ & $4,86 \pm 0,99$ & $<0,01$ & $3,47 \pm 0,91$ & $5,15 \pm 0,99$ & $<0,01$ \\
\hline $\begin{array}{l}\text { Пасивно-апа- } \\
\text { тична соціальна } \\
\text { відгородженість }\end{array}$ & $3,97 \pm 1,00$ & $5,06 \pm 0,97$ & $<0,01$ & $4,29 \pm 0,82$ & $4,91 \pm 0,92$ & $<0,05$ & $3,69 \pm 1,06$ & $5,31 \pm 1,03$ & $<0,01$ \\
\hline $\begin{array}{l}\text { Порушення } \\
\text { абстрактного } \\
\text { мислення }\end{array}$ & $2,69 \pm 0,70$ & $3,97 \pm 1,29$ & $<0,01$ & $2,87 \pm 0,50$ & $3,95 \pm 1,40$ & $<0,01$ & $2,53 \pm 0,81$ & $4,00 \pm 1,15$ & $<0,01$ \\
\hline $\begin{array}{l}\text { Порушення } \\
\text { спонтанності і } \\
\text { плавності мови }\end{array}$ & $2,75 \pm 0,53$ & $3,57 \pm 0,88$ & $<0,01$ & $2,87 \pm 0,50$ & $3,55 \pm 0,86$ & $<0,01$ & $2,64 \pm 0,54$ & $3,62 \pm 0,96$ & $<0,01$ \\
\hline $\begin{array}{l}\text { Стереотипне } \\
\text { мислення }\end{array}$ & $2,46 \pm 0,84$ & $3,80 \pm 1,37$ & $<0,01$ & $2,52 \pm 0,72$ & $3,77 \pm 1,38$ & $<0,01$ & $2,42 \pm 0,94$ & $3,85 \pm 1,41$ & $<0,01$ \\
\hline \multicolumn{10}{|c|}{ Загальна симптоматика } \\
\hline $\begin{array}{l}\text { Соматична } \\
\text { заклопотаність }\end{array}$ & $2,49 \pm 1,63$ & $2,34 \pm 1,51$ & $>0,05$ & $2,26 \pm 1,34$ & $2,41 \pm 1,53$ & $>0,05$ & $2,69 \pm 1,83$ & $2,23 \pm 1,54$ & $>0,05$ \\
\hline Тривога & $4,10 \pm 0,84$ & $5,14 \pm 0,73$ & $<0,01$ & $4,35 \pm 0,71$ & $5,09 \pm 0,81$ & $<0,01$ & $3,89 \pm 0,89$ & $5,23 \pm 0,60$ & $<0,01$ \\
\hline $\begin{array}{l}\text { Почуття про- } \\
\text { вини }\end{array}$ & $1,34 \pm 0,86$ & $1,49 \pm 1,01$ & $>0,05$ & $1,35 \pm 0,84$ & $1,41 \pm 0,85$ & $>0,05$ & $1,33 \pm 0,89$ & $1,62 \pm 1,26$ & $>0,05$ \\
\hline Напруженість & $4,42 \pm 0,89$ & $5,00 \pm 0,73$ & $<0,01$ & $4,77 \pm 0,62$ & $5,05 \pm 0,72$ & $>0,05$ & $4,11 \pm 0,98$ & $4,92 \pm 0,76$ & $<0,05$ \\
\hline $\begin{array}{l}\text { Манірність і } \\
\text { позування }\end{array}$ & $2,16 \pm 1,18$ & $1,80 \pm 1,21$ & $>0,05$ & $2,06 \pm 1,18$ & $1,77 \pm 1,38$ & $>0,05$ & $2,25 \pm 1,18$ & $1,85 \pm 0,90$ & $>0,05$ \\
\hline Депресія & $3,78 \pm 1,31$ & $5,00 \pm 0,84$ & $<0,01$ & $4,19 \pm 1,05$ & $4,95 \pm 0,90$ & $<0,01$ & $3,42 \pm 1,42$ & $5,08 \pm 0,76$ & $<0,01$ \\
\hline $\begin{array}{l}\text { Моторна за- } \\
\text { гальмованість }\end{array}$ & $3,46 \pm 1,20$ & $3,17 \pm 1,48$ & $>0,05$ & $3,35 \pm 1,02$ & $3,09 \pm 1,60$ & $>0,05$ & $3,56 \pm 1,34$ & $3,31 \pm 1,32$ & $>0,05$ \\
\hline $\begin{array}{l}\text { Мало- } \\
\text { контактність }\end{array}$ & $4,25 \pm 1,11$ & $4,06 \pm 1,19$ & $>0,05$ & $4,77 \pm 1,02$ & $4,00 \pm 1,27$ & $<0,05$ & $3,81 \pm 0,98$ & $4,15 \pm 1,07$ & $>0,05$ \\
\hline $\begin{array}{l}\text { Незвичний } \\
\text { зміст думок }\end{array}$ & $2,06 \pm 1,56$ & $1,63 \pm 0,88$ & $>0,05$ & $1,77 \pm 1,26$ & $1,77 \pm 1,02$ & $>0,05$ & $2,31 \pm 1,75$ & $1,38 \pm 0,51$ & $>0,05$ \\
\hline $\begin{array}{l}\text { Дезорієнтова- } \\
\text { ність }\end{array}$ & $1,34 \pm 0,75$ & $1,14 \pm 0,43$ & $>0,05$ & $1,16 \pm 0,52$ & $1,23 \pm 0,53$ & $>0,05$ & $1,50 \pm 0,88$ & $1,00 \pm 0,00$ & $<0,05$ \\
\hline
\end{tabular}




\begin{tabular}{|c|c|c|c|c|c|c|c|c|c|}
\hline $\begin{array}{l}\text { Порушення } \\
\text { уваги }\end{array}$ & $4,19 \pm 0,82$ & $3,94 \pm 0,73$ & $>0,05$ & $4,00 \pm 0,68$ & $3,86 \pm 0,64$ & $>0,05$ & $4,36 \pm 0,90$ & $4,08 \pm 0,86$ & $>0,05$ \\
\hline $\begin{array}{l}\text { Зниження } \\
\text { критичності до } \\
\text { свого стану }\end{array}$ & $5,27 \pm 1,10$ & $4,66 \pm 1,16$ & $<0,05$ & $5,06 \pm 0,96$ & $4,77 \pm 1,11$ & $>0,05$ & $5,44 \pm 1,18$ & $4,46 \pm 1,27$ & $<0,05$ \\
\hline Порушення волі & $4,33 \pm 1,01$ & $4,00 \pm 0,80$ & $>0,05$ & $4,16 \pm 0,93$ & $3,82 \pm 0,80$ & $>0,05$ & $4,47 \pm 1,06$ & $4,31 \pm 0,75$ & $>0,05$ \\
\hline $\begin{array}{l}\text { Послаблення } \\
\text { контролю } \\
\text { імпульсивності }\end{array}$ & $2,91 \pm 0,79$ & $3,11 \pm 0,90$ & $>0,05$ & $3,06 \pm 0,85$ & $3,05 \pm 0,79$ & $>0,05$ & $2,78 \pm 0,72$ & $3,23 \pm 1,09$ & $>0,05$ \\
\hline $\begin{array}{l}\text { Завантаженість } \\
\text { психічними } \\
\text { переживаннями }\end{array}$ & $4,51 \pm 0,86$ & $4,46 \pm 0,74$ & $>0,05$ & $4,26 \pm 0,77$ & $4,32 \pm 0,78$ & $>0,05$ & $4,72 \pm 0,88$ & $4,69 \pm 0,63$ & $>0,05$ \\
\hline $\begin{array}{l}\text { Активна соці- } \\
\text { альна відсторо- } \\
\text { неність }\end{array}$ & $4,54 \pm 0,94$ & $4,26 \pm 1,24$ & $>0,05$ & $4,81 \pm 0,95$ & $4,14 \pm 1,25$ & $>0,05$ & $4,31 \pm 0,89$ & $4,46 \pm 1,27$ & $>0,05$ \\
\hline \multicolumn{10}{|c|}{ Інтегральні показники } \\
\hline Сумарний бал & $\begin{array}{c}102,69 \pm \\
10,43\end{array}$ & $\begin{array}{c}113,83 \pm \\
9,92\end{array}$ & $<0,01$ & $\begin{array}{c}105,23 \pm \\
9,29\end{array}$ & $\begin{array}{c}112,77 \pm \\
10,03\end{array}$ & $<0,01$ & $\begin{array}{c}100,50 \pm \\
10,97\end{array}$ & $\begin{array}{c}115,62 \pm \\
9,85\end{array}$ & $<0,01$ \\
\hline $\begin{array}{l}\text { Тяжкість } \\
\text { позитивної } \\
\text { симптоматики }\end{array}$ & $24,19 \pm 4,75$ & $27,34 \pm 3,59$ & $<0,01$ & $24,90 \pm 4,23$ & $27,41 \pm 3,67$ & $<0,05$ & $23,58 \pm 5,13$ & $27,23 \pm 3,59$ & $<0,05$ \\
\hline $\begin{array}{l}\text { Тяжкість } \\
\text { негативної } \\
\text { симптоматики }\end{array}$ & $23,33 \pm 5,15$ & $31,29 \pm 6,33$ & $<0,01$ & $24,90 \pm 4,32$ & $30,64 \pm 6,57$ & $<0,01$ & $21,97 \pm 5,47$ & $32,38 \pm 5,98$ & $<0,01$ \\
\hline $\begin{array}{l}\text { Вираженість } \\
\text { інших психіч- } \\
\text { них порушень }\end{array}$ & $55,16 \pm 3,33$ & $55,20 \pm 3,75$ & $>0,05$ & $55,42 \pm 3,37$ & $54,73 \pm 3,77$ & $>0,05$ & $54,94 \pm 3,32$ & $56,00 \pm 3,72$ & $>0,05$ \\
\hline Анергія & $12,54 \pm 2,28$ & $14,23 \pm 2,41$ & $<0,01$ & $12,84 \pm 1,98$ & $13,91 \pm 2,60$ & $>0,05$ & $12,28 \pm 2,50$ & $14,77 \pm 2,05$ & $<0,01$ \\
\hline $\begin{array}{l}\text { Порушення } \\
\text { мислення }\end{array}$ & $10,45 \pm 2,61$ & $11,80 \pm 1,84$ & $<0,01$ & $10,68 \pm 2,80$ & $12,00 \pm 1,77$ & $<0,05$ & $10,25 \pm 2,45$ & $11,46 \pm 1,98$ & $>0,05$ \\
\hline Збудження & $10,19 \pm 1,48$ & $10,60 \pm 1,87$ & $>0,05$ & $10,26 \pm 1,65$ & $10,68 \pm 1,91$ & $>0,05$ & $10,14 \pm 1,33$ & $10,46 \pm 1,85$ & $>0,05$ \\
\hline $\begin{array}{l}\text { Параноїдна } \\
\text { поведінка }\end{array}$ & $11,55 \pm 2,66$ & $11,60 \pm 2,35$ & $>0,05$ & $12,10 \pm 2,65$ & $11,59 \pm 2,11$ & $>0,05$ & $11,08 \pm 2,62$ & $11,62 \pm 2,81$ & $>0,05$ \\
\hline Депресія & $11,72 \pm 3,29$ & $13,97 \pm 2,66$ & $<0,01$ & $12,16 \pm 2,71$ & $13,86 \pm 2,85$ & $<0,05$ & $11,33 \pm 3,71$ & $14,15 \pm 2,41$ & $<0,05$ \\
\hline
\end{tabular}

Як видно з таблиці 1, з позитивної симптоматики найтісніше асоційованими з наявністю суїцидальних думок були маячення та галюцинації (у всіх хворих, у чоловіків та жінок), а також збудження (у чоловіків) та розлади мислення (у всіх хворих). Практично вся негативна симптоматика виявилася тісно асоційованою з наявністю суїцидальних думок (за винятком притупленого афекту у чоловіків). Із загальної симптоматики у хворих з суїцидальними думками достовірно частіше виявляли тривогу та депресію (у всіх хворих, у чоловіків та жінок), напруженість (у всіх хворих та у жінок), малоконтактність (у чоловіків) та зниження критичності до свого стану (у всіх хворих та у жінок). 3 інтегральних показників за шкалою PANSS як предиктори суїцидальних думок можна розглядати загальний показник виразності психотичної симптоматики, сумарні показники позитивної та негативної симптоматики, депресії (у всіх хворих, у чоловіків та жінок) показники анергії (у всіх хворих та у жінок) і порушень мислення (у всіх хворих та у чоловіків).
При аналізі особливостей психопатологічної симптоматики шизофренії в контексті наявності суїцидальних дій найбільші відмінності виявлені також для маячення і галюцинацій (у всіх хворих, у чоловіків та жінок), а також збудження (у чоловіків) (табл. 2). Суїцидальні дії виявилися більш тісно асоційованими з негативною симптоматикою, ніж суїцидальні думки, а серед загальної симптоматики - з тривогою і депресією (у всіх хворих, у чоловіків та жінок), напруженістю (у всіх хворих та жінок) та малоконтактністю (у чоловіків). Майже всі інтегральні показники тяжкості психотичної симптоматики у хворих з суїцидальною симптоматикою виявилися достовірно вищими; особливо це стосується сумарного показника тяжкості психотичної симптоматики, інтегральних показників позитивної та негативної симптоматики, анергії (у всіх хворих, у чоловіків та жінок), порушення мислення, збудження (у всіх хворих), депресії (у всіх хворих та у чоловіків).

Нами було вивчено особливості соціальної підтримки хворих на параноїдну шизофренію в 
Огляди літератури, оригінальні дослідження, погляд на проблему, ювілеї контексті суїцидальної поведінки. Як видно з таблиці 3, у хворих з суїцидальними тенденціями $\epsilon$ достовірно нижчими показники соціальної під-

тримки сім'ї, друзів та значущих інших; ці тенденції виявлено у чоловіків, у жінок та у всіх хворих в цілому.

Таблиця 2. Показники позитивної, негативної та загальної симптоматики за даними шкали PANSS у хворих на параноїдну шизофренію з наявністю та відсутністю суїцидальних дій

\begin{tabular}{|c|c|c|c|c|c|c|c|c|c|}
\hline \multirow[b]{2}{*}{ Симптом } & \multicolumn{3}{|c|}{ Усі хворі } & \multicolumn{3}{|c|}{ Чоловіки } & \multicolumn{3}{|c|}{ Жінки } \\
\hline & $\begin{array}{c}\text { без } \\
\text { суїци- } \\
\text { дальних } \\
\text { дій }\end{array}$ & $\begin{array}{l}\text { з наяв- } \\
\text { ністю } \\
\text { суїцидаль- } \\
\text { них дій }\end{array}$ & $\mathrm{P}$ & $\begin{array}{c}\text { без } \\
\text { суїци- } \\
\text { дальних } \\
\text { дій }\end{array}$ & $\begin{array}{l}\text { з наяв- } \\
\text { ністю } \\
\text { суїцидаль- } \\
\text { них дій }\end{array}$ & P & $\begin{array}{c}\text { без } \\
\text { суїци- } \\
\text { дальних } \\
\text { дій }\end{array}$ & $\begin{array}{l}\text { з наяв- } \\
\text { ністю } \\
\text { суїцидаль- } \\
\text { них дій }\end{array}$ & $p$ \\
\hline 1 & 2 & 3 & 4 & 5 & 6 & 7 & 8 & 9 & 10 \\
\hline \multicolumn{10}{|c|}{ Позитивна симптоматика } \\
\hline Маячення & $1,99 \pm 1,01$ & $6,21 \pm 0,42$ & $<0,01$ & $5,24 \pm 0,80$ & $6,17 \pm 0,39$ & $<0,01$ & $4,74 \pm 1,13$ & $6,29 \pm 0,49$ & $<0,01$ \\
\hline Розлади мислення & $3,99 \pm 0,92$ & $4,47 \pm 1,02$ & $>0,05$ & $4,32 \pm 0,96$ & $4,75 \pm 1,14$ & $>0,05$ & $3,67 \pm 0,75$ & $4,00 \pm 0,58$ & $>0,05$ \\
\hline Галюцинації & $3,24 \pm 1,53$ & $5,00 \pm 0,58$ & $<0,01$ & $3,24 \pm 1,41$ & $5,00 \pm 0,60$ & $<0,01$ & $3,24 \pm 1,65$ & $5,00 \pm 0,58$ & $<0,01$ \\
\hline Збудження & $3,59 \pm 1,04$ & $4,05 \pm 0,85$ & $>0,05$ & $3,44 \pm 1,07$ & $4,17 \pm 0,58$ & $<0,05$ & $3,74 \pm 0,99$ & $3,86 \pm 1,21$ & $>0,05$ \\
\hline Ідеї величі & $1,37 \pm 1,01$ & $1,26 \pm 1,15$ & $>0,05$ & $1,51 \pm 1,34$ & $1,00 \pm 0,00$ & $>0,05$ & $1,24 \pm 0,48$ & $1,71 \pm 1,89$ & $>0,05$ \\
\hline $\begin{array}{l}\text { Підозріливість, ідеї } \\
\text { переслідування }\end{array}$ & $3,84 \pm 1,35$ & $4,05 \pm 1,13$ & $>0,05$ & $3,85 \pm 1,35$ & $4,17 \pm 1,03$ & $>0,05$ & $3,83 \pm 1,36$ & $3,86 \pm 1,35$ & $>0,05$ \\
\hline Ворожість & $3,47 \pm 1,20$ & $3,63 \pm 1,07$ & $>0,05$ & $3,41 \pm 1,09$ & $3,83 \pm 1,03$ & $>0,05$ & $3,52 \pm 1,31$ & $3,29 \pm 1,11$ & $>0,05$ \\
\hline \multicolumn{10}{|c|}{ Негативна симптоматика } \\
\hline Притуплений афект & $4,00 \pm 1,09$ & $5,53 \pm 0,61$ & $<0,01$ & $4,20 \pm 0,98$ & $5,33 \pm 0,49$ & $<0,01$ & $3,81 \pm 1,17$ & $5,86 \pm 0,69$ & $<0,01$ \\
\hline $\begin{array}{l}\text { Емоційна } \\
\text { відгородженість }\end{array}$ & $3,90 \pm 1,05$ & $5,47 \pm 0,51$ & $<0,01$ & $4,10 \pm 0,92$ & $5,42 \pm 0,51$ & $<0,01$ & $3,71 \pm 1,15$ & $5,57 \pm 0,53$ & $<0,01$ \\
\hline $\begin{array}{l}\text { Труднощі у } \\
\text { спілкуванні }\end{array}$ & $3,83 \pm 0,92$ & $5,58 \pm 0,77$ & $<0,01$ & $4,05 \pm 0,84$ & $\pm 0,80$ & $<0,01$ & $3,62 \pm 0,96$ & $5,71 \pm 0,76$ & $<0,01$ \\
\hline $\begin{array}{l}\text { Пасивно-апатична } \\
\text { соціальна } \\
\text { відгородженість }\end{array}$ & $4,05 \pm 0,96$ & $5,63 \pm 0,76$ & $<0,01$ & $, 27 \pm 0,78$ & $5,50 \pm 0,67$ & $<0,01$ & $3,83 \pm 1,08$ & $5,86 \pm 0,90$ & $<0,01$ \\
\hline $\begin{array}{l}\text { Порушення } \\
\text { абстрактного } \\
\text { мислення }\end{array}$ & $2,76 \pm 0,73$ & $4,74 \pm 1,15$ & $<0,01$ & $2,85 \pm 0,57$ & $4,92 \pm 1,00$ & $<0,01$ & $2,67 \pm 0,85$ & $4,43 \pm 1,40$ & $<0,01$ \\
\hline $\begin{array}{l}\text { Порушення } \\
\text { спонтанності і } \\
\text { плавності мови }\end{array}$ & $2,80 \pm 0,51$ & $4,05 \pm 0,91$ & $<0,01$ & $2,90 \pm 0,49$ & $4,00 \pm 0,85$ & $<0,01$ & $2,69 \pm 0,52$ & $4,14 \pm 1,07$ & $<0,01$ \\
\hline $\begin{array}{l}\text { Стереотипне } \\
\text { мислення }\end{array}$ & $2,58 \pm 0,89$ & $4,42 \pm 1,39$ & $<0,01$ & $2,61 \pm 0,83$ & $\pm 1,17$ & $<0,01$ & $2,55 \pm 0,94$ & $4,29 \pm 1,80$ & $<0,05$ \\
\hline \multicolumn{10}{|c|}{ Загальна симптоматика } \\
\hline $\begin{array}{l}\text { Соматична } \\
\text { заклопотаність }\end{array}$ & $2,52 \pm 1,65$ & $2,11 \pm 1,24$ & $>0,05$ & $2,39 \pm 1,45$ & $2,08 \pm 1,31$ & $>0,05$ & $2,64 \pm 1,83$ & $2,14 \pm 1,21$ & $>0,05$ \\
\hline Тривога & $4,20 \pm 0,82$ & $5,58 \pm 0,51$ & $<0,01$ & $4,39 \pm 0,70$ & $3 \pm 0,51$ & $<0,01$ & $4,02 \pm 0,90$ & $5,57 \pm 0,53$ & $<0,01$ \\
\hline Почуття провини & $1,40 \pm 0,94$ & $1,37 \pm 0,83$ & $>0,05$ & $1,37 \pm 0,83$ & $1,42 \pm 0,90$ & $>0,05$ & $1,43 \pm 1,04$ & $1,29 \pm 0,76$ & $>0,05$ \\
\hline Напруженість & $4,49 \pm 0,83$ & $5,16 \pm 0,90$ & $<0,01$ & $4,80 \pm 0,56$ & $5,17 \pm 0,94$ & $>0,05$ & $4,19 \pm 0,94$ & $5,14 \pm 0,90$ & $<0,05$ \\
\hline $\begin{array}{l}\text { Манірність і } \\
\text { позування }\end{array}$ & $2,02 \pm 1,15$ & $2,11 \pm 1,41$ & $>0,05$ & $1,93 \pm 1,15$ & $2,00 \pm 1,65$ & $>0,05$ & $2,12 \pm 1,15$ & $2,29 \pm 0,95$ & $>0,05$ \\
\hline Депресія & $3,92 \pm 1,27$ & $5,42 \pm 0,51$ & $<0,01$ & $4,24 \pm 1,02$ & $5,42 \pm 0,51$ & $<0,01$ & $3,60 \pm 1,42$ & $5,43 \pm 0,53$ & $<0,01$ \\
\hline $\begin{array}{l}\text { Моторна } \\
\text { загальмованість }\end{array}$ & $3,36 \pm 1,26$ & $3,37 \pm 1,50$ & $>0,05$ & $3,20 \pm 1,21$ & $3,42 \pm 1,56$ & $>0,05$ & $3,52 \pm 1,31$ & $3,29 \pm 1,50$ & $>0,05$ \\
\hline Малоконтактність & $4,25 \pm 1,11$ & $3,89 \pm 1,20$ & $>0,05$ & $4,71 \pm 1,08$ & $3,58 \pm 1,16$ & $<0,01$ & $3,81 \pm 0,97$ & $4,43 \pm 1,13$ & $>0,05$ \\
\hline $\begin{array}{l}\text { Незвичний зміст } \\
\text { думок }\end{array}$ & $2,00 \pm 1,47$ & $1,53 \pm 0,70$ & $>0,05$ & $1,85 \pm 1,24$ & $1,50 \pm 0,80$ & $>0,05$ & $2,14 \pm 1,68$ & $1,57 \pm 0,53$ & $>0,05$ \\
\hline Дезорієнтованість & $1,33 \pm 0,72$ & $1,05 \pm 0,23$ & $>0,05$ & $1,22 \pm 0,57$ & $1,08 \pm 0,29$ & $>0,05$ & $1,43 \pm 0,83$ & $1,00 \pm 0,00$ & $>0,05$ \\
\hline Порушення уваги & $4,14 \pm 0,81$ & $3,95 \pm 0,71$ & $>0,05$ & $3,95 \pm 0,67$ & $3,92 \pm 0,67$ & $>0,05$ & $4,33 \pm 0,90$ & $4,00 \pm 0,82$ & $>0,05$ \\
\hline $\begin{array}{l}\text { Зниження } \\
\text { критичності до } \\
\text { свого стану }\end{array}$ & $5,24 \pm 1,09$ & $4,26 \pm 1,10$ & $<0,01$ & $5,15 \pm 0,96$ & $4,25 \pm 0,97$ & $<0,05$ & $5,33 \pm 1,20$ & $4,29 \pm 1,38$ & $>0,05$ \\
\hline
\end{tabular}


Продовження табл. 2

\begin{tabular}{|c|c|c|c|c|c|c|c|c|c|}
\hline 1 & 2 & 3 & 4 & 5 & 6 & 7 & 8 & 9 & 10 \\
\hline Порушення волі & $4,25 \pm 1,01$ & $4,05 \pm 0,62$ & $>0,05$ & $4,02 \pm 0,96$ & $4,00 \pm 0,60$ & $>0,05$ & $4,48 \pm 1,02$ & $4,14 \pm 0,69$ & $>0,05$ \\
\hline $\begin{array}{l}\text { Послаблення } \\
\text { контролю } \\
\text { імпульсивності }\end{array}$ & $2,95 \pm 0,78$ & $3,11 \pm 1,05$ & $>0,05$ & $3,05 \pm 0,77$ & $3,08 \pm 1,00$ & $>0,05$ & $2,86 \pm 0,78$ & $3,14 \pm 1,21$ & $>0,05$ \\
\hline $\begin{array}{l}\text { Завантаженість } \\
\text { психічними } \\
\text { переживаннями }\end{array}$ & $4,47 \pm 0,85$ & $4,58 \pm 0,69$ & $>0,05$ & $4,20 \pm 0,75$ & $4,58 \pm 0,79$ & $>0,05$ & $4,74 \pm 0,86$ & $4,57 \pm 0,53$ & $>0,05$ \\
\hline $\begin{array}{l}\text { Активна соціальна } \\
\text { відстороненість }\end{array}$ & $4,54 \pm 0,94$ & $4,00 \pm 1,41$ & $>0,05$ & $4,71 \pm 0,98$ & $3,92 \pm 1,38$ & $>0,05$ & $4,38 \pm 0,88$ & $4,14 \pm 1,57$ & $>0,05$ \\
\hline \multicolumn{10}{|c|}{ Інтегральні показники } \\
\hline Сумарний бал & $\begin{array}{c}103,51 \pm \\
10,12 \\
\end{array}$ & $\begin{array}{c}119,63 \pm \\
7,33\end{array}$ & $<0,01$ & $\begin{array}{c}105,17 \pm \\
8,96\end{array}$ & $\begin{array}{c}119,25 \pm \\
5,94\end{array}$ & $<0,01$ & $\begin{array}{c}101,88 \pm \\
10,99 \\
\end{array}$ & $\begin{array}{c}120,29 \pm \\
9,78\end{array}$ & $<0,01$ \\
\hline $\begin{array}{l}\text { Тяжкість позитивної } \\
\text { симптоматики }\end{array}$ & $24,49 \pm 4,55$ & $28,68 \pm 3,20$ & $<0,01$ & $25,02 \pm 4,04$ & $29,08 \pm 2,94$ & $<0,01$ & $23,98 \pm 5,00$ & $28,00 \pm 3,74$ & $<0,05$ \\
\hline $\begin{array}{l}\text { Тяжкість негативної } \\
\text { симптоматики }\end{array}$ & $23,92 \pm 5,14$ & $35,42 \pm 4,46$ & $<0,01$ & $24,98 \pm 4,30$ & $35,17 \pm 4,11$ & $<0,01$ & $22,88 \pm 5,70$ & $35,86 \pm 5,34$ & $<0,01$ \\
\hline $\begin{array}{l}\text { Вираженість інших } \\
\text { психічних порушень }\end{array}$ & $55,10 \pm 3,15$ & $55,53 \pm 4,68$ & $>0,05$ & $55,17 \pm 3,20$ & $55,00 \pm 4,63$ & $>0,05$ & $55,02 \pm 3,13$ & $56,43 \pm 5,00$ & $>0,05$ \\
\hline Анергія & $12,59 \pm 2,25$ & $15,42 \pm 1,92$ & $<0,01$ & $12,71 \pm 2,09$ & $15,25 \pm 1,91$ & $<0,01$ & $12,48 \pm 2,42$ & $15,71 \pm 2,06$ & $<0,01$ \\
\hline $\begin{array}{l}\text { Порушення } \\
\text { мислення }\end{array}$ & $10,60 \pm 2,55$ & $12,26 \pm 1,33$ & $<0,01$ & $10,93 \pm 2,72$ & $12,25 \pm 0,97$ & $>0,05$ & $10,29 \pm 2,35$ & $12,29 \pm 1,89$ & $>0,05$ \\
\hline Збудження & $10,11 \pm 1,51$ & $11,32 \pm 1,80$ & $<0,01$ & $10,17 \pm 1,70$ & $11,33 \pm 1,72$ & $>0,05$ & $10,05 \pm 1,31$ & $11,29 \pm 2,06$ & $>0,05$ \\
\hline $\begin{array}{l}\text { Параноїдна } \\
\text { поведінка }\end{array}$ & $11,57 \pm 2,62$ & $11,58 \pm 2,27$ & $>0,05$ & $11,98 \pm 2,52$ & $11,58 \pm 2,15$ & $>0,05$ & $11,17 \pm 2,69$ & $11,57 \pm 2,64$ & $>0,05$ \\
\hline Депресія & $12,04 \pm 3,30$ & $14,47 \pm 2,17$ & $<0,01$ & $12,39 \pm 2,90$ & $14,50 \pm 2,15$ & $<0,05$ & $11,69 \pm 3,66$ & $14,43 \pm 2,37$ & $>0,05$ \\
\hline
\end{tabular}

Таблиця 3. Показники соціальної підтримки у хворих на параноїдну шизофренію з наявністю та відсутністю суїцидальних думок та дій

\begin{tabular}{|c|c|c|c|c|c|c|c|c|c|}
\hline \multirow[b]{2}{*}{ Показник } & \multicolumn{3}{|c|}{ Усі хворі } & \multicolumn{3}{|c|}{ Чоловіки } & \multicolumn{3}{|c|}{ Жінки } \\
\hline & $\begin{array}{c}\text { без суїци- } \\
\text { дальних } \\
\text { думок }\end{array}$ & $\begin{array}{c}\text { з наяв- } \\
\text { ністю } \\
\text { суїци- } \\
\text { дальних } \\
\text { думок }\end{array}$ & $P$ & $\begin{array}{c}\text { без суїци- } \\
\text { дальних } \\
\text { думок }\end{array}$ & $\begin{array}{c}\text { з наяв- } \\
\text { ністю } \\
\text { суїци- } \\
\text { дальних } \\
\text { думок }\end{array}$ & $p$ & $\begin{array}{c}\text { без суїци- } \\
\text { дальних } \\
\text { думок }\end{array}$ & $\begin{array}{c}\text { з наяв- } \\
\text { ністю } \\
\text { суїци- } \\
\text { дальних } \\
\text { думок }\end{array}$ & $p$ \\
\hline \multicolumn{10}{|c|}{ Суїцидальні думки } \\
\hline $\begin{array}{l}\text { Соціальна підтримка } \\
\text { сім'ї }\end{array}$ & $0,63 \pm 0,69$ & $0,17 \pm 0,45$ & $<0,01$ & $0,48 \pm 0,57$ & $0,23 \pm 0,53$ & $<0,05$ & $0,75 \pm 0,77$ & $0,08 \pm 0,28$ & $<0,01$ \\
\hline $\begin{array}{l}\text { Соціальна підтримка } \\
\text { друзів }\end{array}$ & $0,96 \pm 0,71$ & $0,49 \pm 0,70$ & $<0,01$ & $0,84 \pm 0,64$ & $0,45 \pm 0,74$ & $<0,05$ & $1,06 \pm 0,75$ & $0,54 \pm 0,66$ & $<0,05$ \\
\hline $\begin{array}{l}\text { Соціальна підтримка } \\
\text { значущих інших }\end{array}$ & $0,72 \pm 0,79$ & $0,26 \pm 0,51$ & $<0,01$ & $0,84 \pm 0,82$ & $0,32 \pm 0,48$ & $<0,05$ & $0,61 \pm 0,77$ & $0,15 \pm 0,55$ & $<0,05$ \\
\hline \multicolumn{10}{|c|}{ Суїцидальні дії } \\
\hline $\begin{array}{l}\text { Соціальна підтримка } \\
\text { сім'ї }\end{array}$ & $0,58 \pm 0,68$ & $0,05 \pm 0,23$ & $<0,01$ & $0,49 \pm 0,60$ & $0,00 \pm 0,00$ & $<0,01$ & $0,67 \pm 0,75$ & $0,14 \pm 0,38$ & $<0,05$ \\
\hline $\begin{array}{l}\text { Соціальна підтримка } \\
\text { друзів }\end{array}$ & $0,95 \pm 0,71$ & $0,16 \pm 0,37$ & $<0,01$ & $0,85 \pm 0,69$ & $0,08 \pm 0,29$ & $<0,01$ & $1,05 \pm 0,73$ & $0,29 \pm 0,49$ & $<0,05$ \\
\hline $\begin{array}{l}\text { Соціальна підтримка } \\
\text { значущих інших }\end{array}$ & $0,66 \pm 0,77$ & $0,26 \pm 0,45$ & $<0,05$ & $0,76 \pm 0,77$ & $0,17 \pm 0,39$ & $<0,05$ & $0,57 \pm 0,77$ & $0,43 \pm 0,53$ & $>0,05$ \\
\hline
\end{tabular}

Показники соціальної підтримки у хворих з суїцидальними діями є надзвичайно низькими, особливо у чоловіків; єдиним показником, за яким не виявлено достовірних відмінностей, $є$ показник соціальної підтримки значущих інших у жі- нок, однак у хворих з суїцидальними діями він також $є$ меншим.

Висновки. 1. Хворим на параноїдну шизофренію з суїцидальною активністю притаманна загалом більша виразність психопатологічної 
Огляди літератури, оригінальні дослідження, погляд на проблему, ювілеї

симптоматики, ніж хворим без суїцидальних тенденцій.

2. В якості основних предикторів суїцидальної поведінки у хворих на параноїдну шизофренію можуть розглядатися висока вираженість негативної симптоматики, маячення, галюцинацій, а також тривоги і депресії.

\section{ЛІТЕРАТУРА}

1. Parnas J. Disordered self in the schizophrenia spectrum: A clinical and research perspective / J. Parnas, M. G. Henriksen // Harv Review of Psychiatry. - 2014. Vol. 22. - P. 251-265.

2. Nordgaard J. Self-disorders, neurocognition, and rationality in schizophrenia: A preliminary study / J. Nordgaard, R. Revsbech, M.G. Henriksen // Psychopathology. 2015. - Vol. 48. - P. 310-316.

3. Self-stigma and schizophrenia: a cross-sectional study / K. Vrbova, J. Prasko, M. Holubova [et al.] // Neuropsychiatric Diseases Treatment. - 2016. - Vol. 12 (24). P. 3011-3020.

4. Braga R. J. Anxiety comorbidity in schizophrenia / R. J. Braga, G. P. Reynolds, S. G. Siris // Psychiatry Research. 2013. - Vol. 210 (1). - P. 1-7.

5. Impact of social anxiety on social cognition and functioning in patients with recent-onset schizophrenia spectrum disorder / A. M. Achim, R. Ouellet, M. A. Lavoie [et al.] // Schizophrenia Research. - 2013. - Vol. 145 (1-3). P. 75-81.

6. Insight, positive and negative symptoms, hope, depression, and self-stigma: a comprehensive model of mutual influences in schizophrenia spectrum disorders / B. Schrank, M. Amering, A. G. Hay [et al.] // Epidemiology Psychiatric Science. - 2014. - Vol. 23(3). - P. 271-279.

\section{REFERENCES}

1. Parnas, J., \& Henriksen, M.G. (2014). Disordered self in the schizophrenia spectrum: A clinical and research perspective. Hard Review of Psychiatry, 22, 251-265.

2. Nordgaard, J., Revsbech, R., \& Henriksen, M.G. (2015). Self-disorders, neurocognition, and rationality in schizophrenia: A preliminary study. Psychopathology, 48, 310-316.

3. Vrbova, K., Prasko, J., \& Holubova, M. (2016). Self-stigma and schizophrenia: a cross-sectional study. Neuropsychiatric Diseases Treatment, 12 (24), 3011-3020.

4. Braga, R.J., Reynolds, G.P., \& Siris, S.G. (2013). Anxiety comorbidity in schizophrenia. Psychiatry Research, $210(1), 1-7$.

5. Achim, A.M., Ouellet, R., Lavoie, M.A., Vallières, C., Jackson, P.L., \& Roy, M.A. (2013). Impact of social anxiety on social cognition and functioning in patients with recent-onset schizophrenia spectrum disorder. Schizophrenia Research, 145 (1-3), 75-81.
3. Хворим на параноїдну шизофренію з суїцидальними тенденціями притаманний низький рівень соціальної підтримки сім'ї, друзів та значущих інших; більшою мірою ця тенденція виражена у чоловіків.

Перспективи подальших досліджень пов'язані з пошуком шляхів профілактики суїцидальної поведінки у хворих на параноїдну шизофренію.

7. Self-harm and suicide attempts in Schizophrenia / K. Jakhar, R. P. Beniwal, T. Bhatia, S.N. Deshpande // Asian Journal of Psychiatry. - 2017. - Vol. 30. - P. 102-106.

8. Guloksuz R. S. The slow death of the concept of schizophrenia and the painful birth of the psychosis spectrum / R. S. Guloksuz, J. van Os // Psychological Medicine. 2017. - Vol. 48(2). - P. 1-16.

9. A biopsychosocial evaluation of the risk for suicide in schizophrenia / N. C. Hettige, A. Bani-Fatemi, I. Sakinofsky, V. De Luca // CNS Spectrums. - 2017. - Vol. 24. - P. 1-11.

10. Suicide prevention in schizophrenia spectrum disorders and psychosis: a systematic review / T. Donker, A. Calear, J. B. Grant [et al.] //BMC Psychology. -2013. - Vol. 1 (1). P. 11-16.

11. Fuller-Thomson E. Schizophrenia and suicide attempts: Findings from a representative community-based Canadian sample / E. Fuller-Thomson, B. Hollister // Schizophrenia Research and Treatment. - 2016. - Vol. 16. - P. 34-36.

12. Suicide in the early stage of schizophrenia / A. Ventriglio, A. Gentile, I. Bonfitto [et al.] // Frontiers in Psychiatry. - 2016. - Vol. 7. - P. 116.

13. Risk factors for suicidality in patients with schizophrenia: A systematic review, meta-analysis, and meta-regression of 96 Studies / R. M. Cassidy, F. Yang, F. Kapczinski, I. C. Passos // Schizophrenia Bulletin. -2017. - Vol. 9. - P. 21-23. 
Огляди літератури, оригінальні дослідження, погляд на проблему, ювілеї

11. Fuller-Thomson, E., \& Hollister, B. (2016). Schizophrenia and suicide attempts: Findings from a representative community-based Canadian sample. Schizophrenia Research and Treatment, 16, 34-36.

12. Ventriglio, A., Gentile, A., Bonfitto, I., Stella, E., Mari, M., Steardo, L., \& Bellomo, A. (2016). Suicide in the early stage of schizophrenia. Frontiers in Psychiatry, 7, 116.

13. Cassidy, R.M., Yang, F., Kapczinski, F., \& Passos, I.C. (2017). Risk factors for suicidality in patients with schizophrenia: A systematic review, meta-analysis, and meta-regression of 96 studies. Schizophrenia Bulletin, 9, 21-23.

\title{
ОСОБЕННОСТИ СУИЦИДАЛЬНОГО ПОВЕДЕНИЯ БОЛЬНЫХ ПАРАНОИДНОЙ ШИЗОФРЕНИЕЙ С РАЗНЫМИ КЛИНИКО-ПСИХОПАТОЛОГИЧЕСКИМИ И СОЦИАЛЬНО-ПСИХОЛОГИЧЕСКИМИ ХАРАКТЕРИСТИКАМИ
}

๑Я. Ю. Марункевич

\author{
Винницкий национальный медицинский университет имени Н. И. Пирогова
}

РЕзЮМЕ. Шизофрения - это тяжелое психическое заболевание, которое сопровождается высоким риском суицидального поведения.

Цель - изучить особенности суицидального поведения больных параноидной шизофренией в контексте выраженности продуктивной, негативной и общей симптоматики шизофрении, а также социальной поддержки больных.

Материал и методы. При соблюдении принципов биомедицинской этики были клинически обследованы 53 мужчины и 49 женщин, больных параноидной шизофренией, и проведены оценка выраженности симптоматики шизофрении с помощью шкалы PANSS и обследование с использованием шкалы MSPSS.

Результаты. У больных с суицидальными мыслями и суицидальными действиями выявлены достоверно более высокие показатели бреда, галлюцинаций, возбуждения, расстройств мышления, всех составляющих негативной симптоматики, тревоги, депрессии, малоконтактности, снижения критичности к своему состоянию, а также интегральных показателей выраженности психотической симптоматики, продуктивной и негативной симптоматики, депрессии, анергии и нарушений мышления. У больных с суицидальными действиями показатели выраженности психопатологической симптоматики и различия, по сравнению с больными с отсутствием суицидальных тенденций, больше, чем у больных с суицидальными мыслями. У больных с суицидальными тенденциями выявлены достоверно более низкие показатели социальной поддержки семьи, друзей и значимых других; эти тенденции выявлены у мужчин, у женщин и у всех больных в целом, причем у больныхссуицидальными действиями эти показатели очень низкие, особенно у мужчин.

Выводы. Выявленные закономерности свидетельствуют о том, что больным параноидной шизофренией с суицидальной активностью присуща в целом большая выраженность психопатологической симптоматики, по сравнению с больными без суицидальных тенденций; в качестве основных предикторов суицидального поведения у больных параноидной шизофренией могут рассматриваться высокая выраженность негативной симптоматики, бред, галлюцинации, а также тревога и депрессия, а также о том, что больным параноидной шизофренией с суицидальными тенденциями присущ низкий уровень социальной поддержки семьи, друзей и значимых других; эта тенденция более выражена у мужчин.

КЛючЕВЫЕ СЛОВА: параноидная шизофрения; суицидальное поведение.

\section{FEATURES OF SUICIDAL BEHAVIOR OF PATIENTS WITH PARANOID SCHIZOPHRENIA WITH DIFFERENT CLINICAL-PSYCHOPATHOLOGICAL AND SOCIO-PSYCHOLOGICAL CHARACTERISTICS}

\section{Pyrohov Vinnytsia National Medical University}

๑Ya. Yu. Marunkevych

SUMMARY. Schizophrenia is a serious mental illness that is accompanied by a high risk of suicidal behavior.

The aim of the study - to learn the peculiarities of suicidal behavior of patients with paranoid schizophrenia in the context of the severity of productive, negative and general symptoms of schizophrenia, as well as social support for patients.

Material and Methods. Following the principles of biomedical ethics, 53 men and 49 women with paranoid schizophrenia were clinically examined and an assessment of the severity of the symptoms of schizophrenia was carried out using the PANSS scale and a survey using the MSPSS scale. 
Огляди літератури, оригінальні дослідження, погляд на проблему, ювілеї

Results. In patients with suicidal thoughts and suicidal actions, significantly higher rates of delusions, hallucinations, arousal, thinking disorders, all components of negative symptoms, anxiety, depression, low contact, decreased criticality to their condition, as well as integral indicators of the severity of psychotic symptoms, productive and negative symptomatology, depression, anergy and mental disorders. In patients with suicidal actions, the severity of psychopathological symptoms and differences in comparison with patients with a lack of suicidal tendencies are greater than in patients with suicidal thoughts. In patients with suicidal tendencies, significantly lower indices of social support for the family, friends and significant others were revealed; these trends are found in men, women and all patients in general, and in patients with suicidal actions, these rates are very low, especially in men.

Conclusions. The revealed regularities testify that the patient with paranoid schizophrenia with suicidal activity is generally characterized by a greater degree of psychopathological symptomatology, in comparison with patients without suicidal tendencies; as the main predictors of suicidal behavior in patients with paranoid schizophrenia, high severity of negative symptoms, delusions, hallucinations, as well as anxiety and depression, and the fact that patients with paranoid schizophrenia with suicidal tendencies have a low level of social support for family, friends and other significant persons; this trend is more pronounced in men.

KEY WORDS: paranoid schizophrenia; suicidal behavior. 